\title{
Ascending to the Imperial Throne: Kojong's Elevation from King to Emperor and British Responses, 1895-1898*
}

Euysuk Kwon**

\section{Introduction}

On October 12, 1897, King Kojong (r. 1864-1907) officially proclaimed that he would assume the title of emperor and change the name of the state from Chosón to the Empire of Taehan. The establishment of the Empire of Taehan was significant not only because it was the last Korean monarchy that existed before the Japanese annexation of Korea on August 29, 1910, but also it was the first Korean monarchy to openly claim to be an empire, something that was the exclusive right of the Chinese ruler in the pre-modern Sinocentric world order. Therefore, Kojong's accession to emperor in 1897 was a remarkable event underpinning Korean independence, which had been severely challenged by the Japanese assassination of Queen Min of 1895 and Kojong's asylum at the Russian Legation from 1896 to 1897.

From the mid-1970s, there have been major debates on whether the Taehan Empire and the Korean imperial family were modern and pro-

\footnotetext{
* This work was supported by the Ministry of Education of the Republic of Korea and the National Research Foundation of Korea (NRF-2017S1A6A3A02079082).

** HK+ Research Professor, Center for Northeast Asian Humanities and Social Science, Wonkwang University
} 
gressive institutions. ${ }^{1}$ Since then, many scholars have examined the importance of the assumption of the emperor title as well as various aspects of the Taehan Empire. ${ }^{2}$ Their studies reveal that the main objective of Kojong's assumption of the title of emperor was to stabilize domestic politics and to reclaim Korea's independent status. Since Kojong's accession to emperor completely changed Sino-Korean relations, which had been a Sinocentric tributary system, some studies have focused on its impact on Sino-Korean relations ${ }^{3}$ yet relatively few examine other coun-

1 Kim Yongseop and Kang Mankil positively evaluated the role of the Empire of Taehan and the Korean Imperial Family, whereas Shin Yongha and Jhin Dukyu emphasised the limitations of the Kwangmu Reform and the Empire of Taehan. Kim Yongseop, Han'guk Kündae Nongŏpsa Yŏn'gu (Seoul: Ilchogak, 1975); Kang Mankil, "Taehanjegugŭi Sŏnggyŏk [The Characteristics of the Empire of Taehan], " Ch'angjakkwa Pip'yŏng [Creation and Criticism] 48, 1978; Shin Yongha, "Kwangmugaehyŏngnonŭi Munjejŏm [The Problems of the Kwangmu Reform Debates]," Ch'angjakkwa Pip'yŏng [Creation and Criticism] 49, 1978; Jhin Dukyu, "Taehanjegugŭi Kwŏllyŏkkujoe Kwanhan Chŏngch'isajŏk Inshik [The Significance of the Power Structure of the Empire of Taehan in Political History]" in Taehanjegukyŏn'gu[The Studies of the Empire of Taehan], ed. Institute of Korean Culture, Ewha Women's University (Seoul: Ewha Women's Unversity, 1883).

2 Key studies include Center for Korean Studies, Hallym University, Taehanjegukŭn Kŭndaegukkain'ga[Is the Empire of Taehan a Modern State?] (Seoul: P'urŭnyŏksa, 2006); Lee Taejin, Kojongshidaeŭi Chaejomyŏng[Shedding New Light on the Kojong Era] (Seoul: T'aehaksa, 2000); Seo Younghee, Taehanjeguk chŏngch'isa yŏn'gu[The Study of the Political History of the Great Han Empire] (Seoul: Seoul National University Press, 2003); Tatsuhiko Tsukiashi, Chosŏnŭi Kaehwasasanggwa Naesyŏnŏllijŭm[The Enlightenment Ideas and Nationalism of Chosŏn], trans. Choi Duksoo (Paju: Yŏllinch'aektŭl, 2014); and Cho Jaegon, Hwangje Chungshimŭi Kŭndae Kukkach'eje Hyŏngsŏng : Kojonggwa Taehanjeguk[The Emperor-Centred Formation of a Modern State System] (Seoul: Yŏksagonggan, 2020).

3 Song Kuejin, "Transformation of the Dualistic International Order into the Modern Treaty System in the Sino-Korean Relationship," International Journal of Korean History 15, no.2 (August 2010): 97-126; Lee Eunja, "Hanjung Kŭndae Oegyoŭi Shirhŏm, 1895-1905Nyŏn[The Challenges to the Modern Diplomacy Between Korea and China, 1895-1905]," Chunggukkünhyöndaesayŏn'gu[Korean Studies of 
tries' responses. ${ }^{4}$

Britain was one of those countries who had to deal with the change of Kojong's title. Since the ratification of the Anglo-Korean Treaty of 1883, Britain's Korea policy was to recognize Qing China's traditional suzerainty over Korea and to rely upon Qing China to maintain the status quo in the region. As one of the strongest Western powers that established an informal empire in China, Britain was a crucial actor in the international politics of Northeast Asia. However, after Japan's triumph in the SinoJapanese War of 1894-5 and the subsequent signing of the Treaty of Shimonoseki, which recognized Korea's complete independence from Qing China (1644-1912), the focus of Britain's Korea policy shifted from Qing China's dominance over Korea to the independence of Korea. ${ }^{5}$ Remarkable research on Anglo-Korean relations in the late 19th century and the early 20th century have been conducted by several scholars such as $\mathrm{Ku}$ Taeyul and Kim Hyunsoo who show how Britain built a diplomatic network in Northeast Asia and what the characteristics of Britain's Northeast Asian policies were in the $19^{\text {th }}$ century. Kim Wonsoo examine AngloKorean relations before and after the Russo-Japanese War (1904-5) in the context of Britain's worldwide strategy. ${ }^{6}$ Han Seunghoon's several stud-

Modern Chinese History] 58 (June 2013): 1-25; Kim Hyeongchong, "19segi Kŭndae Hanjung Kwan'gyeŭi Pyŏnyong[Transformation of Korean-Chinese Relations in the 19th Century]," Tongyangsahakyŏn'gu[Journal of Asian Historical Studies] 140 (September 2017): 223-270.

4 Lee Minwon, "Taehanjegugŭi Sŏngnipkwajŏnggwa Yŏlganggwaŭi Kwan'gye [On the Response of the Foreign Powers to the Establishment of the Taehan Empire]," Han'guksa Yŏn'gu [The Journal of Korean History] 64 (March 1989): 117-145; Cho, Hwangje Chungshimŭi Kŭndae Kukkach'eje Hyŏngsŏng : Kojonggwa Taehanjeguk[The Emperor-Centred Formation of a Modern State System].

5 Salisbury to Satow, 25 October 1895, No. 22, Foreign Office (FO) 405/65.

6 Ku Taeyul, "Chayujuŭi yŏlgangŭi Hanbando Chinch'ulgwa Kŭ Sŏnggyŏk, 18701910[The Nature of Liberal Powers' Advance towards the Korean Peninsula]," Han'guksasanggwa Munhwa[Korean Ideology and Culture] 21 (September 2003): 7-54; Kim Hyunsoo, "Yŏngguk Oegyojŏngch'aegŭi Pyŏnhwach'ui, 1860 1914: Taejungguk Oegyojŏngch'aek Chungshimŭro[Trend of the British Foreign Policy 
ies covering the history of Anglo-Korean relations between 1883 and 1910 also help to understand the development of the bilateral relationship. ${ }^{7}$ However, Britain's response to the question of Kojong's assumption of the title of emperor has been hardly examined even though the event coincided with the change of Britain's Korea policy that started to emphasize the importance of the independence of Korea.

This article intends to fill the gap by examining how Kojong pushed for his declaration as emperor and how Britain responded to the question. Firstly, it discusses the failed attempt to proclaim the emperor title immediately after the Japanese murder of Queen Min in October 1895 and how

to China, 1860 1914]," Tongyanghak[The Oriental Studies] 67 (2017): 91-108; Kim Wonsoo, “4kuk'yŏpchoch'ejewa Hanilbyŏnghabŭi Kukchegwan'gye, 1907 1912: Yŏnggugŭi Tongmaenghyŏpsangoegyowa Yŏn'gyehayŏ[International Relations of the Quadruple Entente System and the Japanese Seizure of Korea, 1907 1912 : Related to the British Entente Policy]," Dongbuga Yeoksa Nonchong 29 (September 2010): 55-96; Kim Wonsoo, "Ilbonŭi Taehanjeguk Pohoguk'wawa Yŏnggugŭi Taehanjŏngch'aek: Yŏngiltongmaenggwa Rŏilchŏnjaengŭl Chungshimŭro[British Policy toward Korea before and after Japan`s Protectoration of Korea: Focused on the Anglo-Japanese Alliance and the Russo-Japanese War]," Han'guktongnibundongsayŏn'gu[Journal of Korean Independence Movement Studies] 51 (August 2015): 187-215.

7 Han Seunghoon, “Choyŏngjoyak(1883. 11)kwa Pulp'yŏngdŭngjoyakch'ejeŭi Chaejŏngnip[The Treaty Concluded between Korea and Britain in 1883 and the Reconstruction of the Unequal Treaty System]," Han'guksayŏn'gu[Journal of Korean History] 135 (December 2006): 215-250; "19segi Huban Chosŏnŭi Taeoejŏngch'aek Kijowa Kŭ Shirhyŏn: Kyunsejŏngch'aekkwa Kŏjungjojŏngŭi Ch'ujin[Establishment and Enforcement of Foreign Policy in the Late 19th Century of Chosŏn with Regard to Balance of Power and Good Offices]," Han'gukkŭnhyŏndaesayŏn'gu[Journal of Korean Modern and Contemporary History] 83 (December 2017): 7-38; “Ch'ŏngilchŏnjaeng Chikchŏn Yŏnggugŭi oegyojŏk Kansŏp Shilp'aewa P'aegwŏnjŏk Chiwi Kyunyŏl: Yŏnggugŭi Taejosŏnjŏngch'aekkwa Kwallyŏnhaesŏ[Britain's failure to intervene in diplomacy before the first SinoJapanese War and the Cracking of its Hegemony: with Regard to British Policy toward Korea]," Han'guktongyangjŏngch'isasangsayŏn'gu[The Review of Korean and Asian Political Thoughts] 19, no.2, (September 2020): 63-97. 
Britain saw it. Secondly, it demonstrates how cautiously Kojong planned to introduce the emperor title while avoiding any possible foreign opposition during the period February to September 1897. It shows a wide gap between Britain and Korea in the impact of the assumption of emperor title. Finally, it analyzes how Britain acknowledged Kojong's accession to emperor and what the main reason was behind the promotion of the diplomatic rank of the British representative in Korea, which coincided with Kojong's ascent to the imperial throne.

\section{Britain's Rejection of the Attempted Assumption of the Emperor Title in $\mathbf{1 8 9 5}$}

Traditionally, the kings of the Chosŏn Dynasty (1392-1897) respected their tributary status in their relationship with China and recognized it by only using the term 'emperor' for Chinese rulers. However, since Korea signed treaties with foreign powers from 1876, all of which stipulated that 'Korea was an independent state,' the assumption of the imperial title began to be considered a suitable option to reflect Korea's independent status. It was mentioned for the first time on December 4, 1884, when Kim Okkyun initiated the Kapsin coup to overthrow the conservative regime and to subsequently establish a progressive government. Two days after the coup, his party the Kaehwadang [Enlightenment Party] announced 14 political principles, one of which stipulated the end of the tributary relationship with China. ${ }^{8}$ Kim Ok-Kyun apparently considered the acceptance of the title of emperor as an explicit way to achieve this goal. ${ }^{9}$ The question of the imperial title also arose as to how the sover-

8 For an account of the Kapsin Coup of 1884, see Harold F. Cook, Korea's 1884 Incident: Its Background and Kim Ok-Kyun's Elusive Dream (Seoul: Royal Asiatic Society Korea Branch, 1972) and Park Eunsook, Kapsin chŏngbyŏn Yŏn'gu [A Study of Kapsin Coup] (Seoul: Yŏksabip'yŏngsa, 2005).

9 Kwach'ŏn, Korea, Chuhan Ilbon'gongsagwan Kirok [The Records of the Japanese 
eign of Korea should be addressed during the ratification of the AustroKorean Treaty of $1892 .{ }^{10}$

In 1894, when the Sino-Japanese War broke out and the Korean Court came under Japanese occupation, the adaptation of the title of emperor started to be seriously discussed. On July 29, right after the outbreak of the Sino-Japanese War, Japanese Minister Ōtori Keisuke suggested the formal introduction of the imperial title. ${ }^{11}$ In addition to the abolition of the China-Korea Accord of 1882, it intended to undermine the foundation of China's claim for traditional suzerainty over Korea. Kojong declined to assume the imperial title at that time but later in January 1895, Kojong and the Korean court modified a royal regulation regarding the styles of address and changed the previous form 'Chusang Chŏnha' (His Royal Majesty) into 'Taegunju P'yeha' (His Imperial Majesty). ${ }^{12}$ The term 'Taegunju P'yeha,' which was only meant for an emperor, started to be used in the middle of the 1880s when Kojong was addressed in correspondences with foreign representatives. In January 1895, when Chinese influence was completely removed by the Japanese military in Korea, Kojong and the Korean government eventually made it an official address that would be openly used within the Korean court. ${ }^{13}$ This demonstrates that both Korea and Japan were interested in establishing imperial status for Korea at that time. ${ }^{14}$ However, since the Korean cabinet was heavily pro-Japanese due to their military dominance in the country during the

Legation Korea, hereafter 'CIK'], Katō to Ōkuba, 25 October 1897, No. 71 (Confidential), Vol. 12; Hwang Hyŏn, Wanyŏk Maech'ón yarok [Historical Records by Hwang Hyŏn] (Seoul: Kyomunsa, 1994), 156-157.

10 CIK, Katō to Ōkuba, 25 October 1897, No. 71 (Confidential), Vol. 12.

11 Hwang Hyŏn, Wanyŏk Maech'ón yarok, 296.

1217 December 1894 (Lunar Calendar), Vol.32, Kojong Sillok.

13 For more information on the origin of the term 'Taegunju P'yeha', see Min Hoisoo, "Kabogaehyŏng ijŏn chosŏnŭi hwangjegung yongŏ sayong [The Use of the Terms for the Empire in Korea before 1894]," Kyujanggak 55 (December 2019): 130-144. 14 Lee Minwon, "Taehanjegugŭi Sŏngnipkwajŏnggwa Yŏlganggwaŭi Kwan'gye," 123-124. 
Sino-Japanese War, it should be seen as part of Japan's scheme to tackle Chinese influence by supporting Korea's independent status.

The change of title was again discussed on October 15, 1895, right after the Japanese assassination of Queen Min and the following reshuffling of the Korean cabinet. Yun Ch'iho, then Vice Minister of Foreign Affairs, described the discussion of the matter in his diary.

At 4 p.m., a meeting of all the Ministers and Vice Ministers was called in the Cabinet to discuss the advisability of changing the title of 'King' to that of 'Emperor.' Messrs. Cho [Cho Hŭiyŏn], Kwon [Kwŏn Hyŏngchin], Chung [Chŏng Pyŏngha] advocated the step very strongly. Kwon said that this was absolutely necessary to make the people realize their independence from China. I told them that while neither Japan nor China would honor Corea an iota more for putting on the imperial title, we would evoke the ridicule of the sensible. The Minister of F.O. [Kim Yunsik] and the Prime Minister [Kim Hongjip] agreed with me but they dared not oppose the majority - supported the Army Officers [U Pŏmsŏn, I Tuhwang]. ${ }^{15}$

Yun's diary clearly demonstrates that the change of the royal title was supported and promoted by young Korean officers and pro-Japanese ministers who were actively involved in the assassination of the queen. Furthermore, because the Korean court and cabinet were under occupation by Japanese troops since the incident, it is obvious that these Korean ministers and officers pushed forward the policy on behalf of Japan.

A correspondence by British Consul-General Walter C. Hillier also hints that the change of the title had been originally planned by the Japanese. Just like the pro-Japanese Korean officers and ministers, former Japanese Minister Miura Gorō and local Japanese newspapers also argued that it would be necessary for "demonstrating to the Korean nation and

15 Yun Chiho, Yun Chi-Ho Ilgi 4, 74-75. 
the world at large the complete independence of Korea and her equality with her two great neighbours." 16 Russian Minister Karl Ivanovich Waeber also confirmed that he had been told by Kojong that pro-Japanese ministers had forced him to approve the proposal.

It was Waeber that strongly opposed the promotion of the king's status to that of emperor. Since the end of the Sino-Japanese War and the subsequent Triple Intervention of 1895, Russia tried to maintain a close relationship with the Min clan, one of the most powerful political groups within the Korean court. Waeber was particularly upset because the Japanese murder of Queen Min clearly intended to remove the pro-Russian group from Korean politics and attempted to strengthen their influence in the country. Thus, he refused to recognize Kojong's assumption of the title of emperor as well as any other policies pursued by the current Korean government, who were clearly under the strong influence of Japan. ${ }^{17}$ Hillier also shared the same view as Waeber's that the status as king would be sufficient to underline Korean independence because all European sovereigns whose governments concluded treaties with Korea were designated as 'King' or 'Queen' in the same manner. ${ }^{18}$

What particularly concerned Hillier was not the change of status but a potential threat to Kojong or the Crown Prince, which might be posed during the ceremony of the title announcement. He was aware that the Japanese-drilled Korean guards, under the command of Cho Hŭiyŏn, encircled the Council Chamber and stopped ministers from leaving until they agreed with the proclamation of emperor title, which Kojong did not

16 Hillier to O'Conor, 25 October 1895, Inclosure 8 in No. 128, FO 405/65.

17 Kim Jongheon, “Ch'ŏngil Chŏnjaeng Ihu Chaehan Rŏshia Oegyogwanŭi Hwaltonge Kwanhan Koch'al, 1894-1895[A Study on Activities by Russian Diplomats after the Sino-Japanese War, 1894-1895]," Süllabŭhakpo[Slave Newpaper] 24, no.2 (Jun 2009): 280-281.

18 On the other hand, McLeavy Brown asserted that the emperor title should be not be employed until all other Treaty Powers agreed with the implication. Hillier to O'Conor, 25 October 1895, Inclosure 8 in No. 128, FO 405/65. 
intend to obtain under such circumstances. ${ }^{19}$ Furthermore, when it was announced that the ceremony would be held without the presence of the Crown Prince, who had never been apart from Kojong due to physical threats since the Japanese murder of Queen Min, Hillier, Waeber and American Minister John M. B. Sill worried that the ceremony might be used by conspirators to harm Kojong and the Crown Prince. ${ }^{20}$

Therefore, Hillier and other representatives decided to tell Japanese Minister Komura Jutarō to exert his authority, "which he undoubtedly possesses," upon pro-Japanese Korean officers in charge of the security of the palace. ${ }^{21}$ Komura answered that he had been instructed by the Japanese government not to recognize the proclamation of the imperial title and assured that he would do everything he could do to prevent the ceremony. As he promised, he had a meeting with Cho Hŭiyŏn and forced him to cancel the ceremony under the pretense of disagreement among foreign representatives. ${ }^{22}$

The British consulate-general opposed the idea of Kojong's assumption of the imperial title for three reasons. Firstly, Hillier believed that the imperial title would be unnecessary if Korea wanted to be recognized as a completely independent state. In accordance with international diplomacy, King, Kojong's current title was sufficient to be acknowledged as an independent sovereign and thus he believed it would have no actual impact even if the title was changed to emperor. However, the second and more compelling reason for British opposition was because it was planned and promoted by Japan and pro-Japanese Korean ministers. From the very beginning, foreign representatives already knew that Japan was behind the murder of Queen Min and the reshuffling of the Korean cabinet. Hillier was also aware the proposal of the emperor title had been made against Kojong's will at that time and thus it was inappropriate for Hillier to

19 Hillier to O'Conor, 25 October 1895, Inclosure 8 in No. 128, FO 405/65.

20 Hillier to O'Conor, 27 October 1895, Inclosure 5 in No. 129, FO 405/65.

21 Hillier to O'Conor, 27 October 1895, FO 405/65.

22 Hillier to O'Conor, 27 October 1895, FO 405/65. 
agree with the assumption of the title. Thirdly, Hillier understood that Kojong had been physically threatened by Japanese-trained troops occupying the Korean palace. Hillier worried that the ceremony for the assumption of emperor title would be exploited to harm Kojong and the Crown Prince, which would further destabilize Korean politics.

For these reasons, Hillier joined other foreign representatives and appealed to the Japanese Legation to solve the current crisis. Thus, Komura discouraged the proclamation of the title of emperor because they could not risk further confrontation with foreign representatives. It is worth noting that the assumption of the imperial title was proposed right after the murder of Queen Min who had vigorously intervened in political affairs by inviting foreign powers to counterbalance Japanese influence. If Japan successfully forced Kojong to accept the title of emperor and to subsequently announce Korea's complete independence from any foreign power, then the assassination of Queen Min could have been justified as an elimination of a threat to the integrity of the nation. However, foreign representatives knew Japan's engagement in the matter from the very beginning of the incident and thus Japan was unable to disguise the murder as an accident committed by Japanese-drilled Korean guards.

\section{The Gap between Britain and Korea Regarding the Question of the Assumption of the Imperial Title}

Discussions over the acceptance of the title emperor were resumed in early 1897 when Kojong left the Russian legation and returned to Kyŏngun'gung Palace (now Tŏksu Palace), and the political circumstances were more favorable for the Korean court to pursue the proclamation of the imperial title than before. One of the most prominent differences was the lack of a strong foreign presence surrounding Kojong. Unlike in October 1895, when the royal palace was practically seized by proJapanese troops and officers, in February 1897 Kojong was relatively free from foreign aggression. His asylum at the Russian legation not only 
damaged Japanese influence within the Korean government, it also led both Russia and Japan to reach an agreement to solve the bilateral confrontation over Korea. The Romanov-Yamagata agreement of 1896 stipulated that both governments should recognize the status quo within the country. Such conditions allowed Kojong to pursue more independent foreign policies.

Also, Chinese influence had been continuously challenged and reduced since 1894. Traditionally in Northeast Asia, the sovereigns of the tributaries of Chinese Empires not only had to address themselves as 'Wang' (king or prince), but also, they had to use Chinese era names to recognise the suzerainty of the Chinese empire. ${ }^{23}$ Therefore, if a tributary state attempted to deny Chinese suzerainty and proclaim independence, both Ch'ingje (the proclamation of the emperor title) and Kŏnwŏn (the introduction of an era name) needed to be implemented. As is already discussed, Kojong adapted the form of address of emperor (Taegunju P'yeha) in January 1895. ${ }^{24}$ Additionally, on July 30, 1894, a new era name 'Kaeguk' (where years were numbered from the beginning of the Chosŏn Dynasty in 1392) was introduced by Kojong and the Korean court and replaced the previous Chinese era name. ${ }^{25}$ Subsequently, on December 30, 1895, when Kojong abolished the lunar calendar as part of his reforms, he introduced a new era name called 'Kŏnyang' (the introduction of the Western Calendar). Although the replacement was made by the proJapanese Korean Cabinet as part of the modernization reforms, it eventually contributed to removing the traditional symbols of the China-centerd tributary system.

Discussion of the title of emperor resumed in May 1897. While Chinese influence had been weakened by Japan since 1894, Japanese and

23 For an account of the Sinocentric world order, see Kim Keyhiuk, The Last Phase of the East Asian World Order: Korea, Japan and the Chinese Empire, 1860-1882 (Berkeley, California: University of California Press, 1980).

24 December 17, 1894 (Lunar Calendar), Vol.32, Kojong Sillok.

2528 June 1894 (Lunar Calendar), Vol.31, Kojong Sillok. 
Russian influences were also challenged by Kojong's year long asylum at the Russian legation from 1896. Once Kojong left the Russian legation for Kyŏngun'gung Palace and became less dependent on foreign influence, he eventually planned to raise sovereign status by assuming the title of emperor (Ch'ingje). From May 1897, approximately three months after Kojong's return to the palace, high-ranking officials in the Korean government sent memorials to the throne calling for his official assumption of the title of emperor. Whenever Kojong received such memorials, he officially condemned that such suggestions were "very wrong."26 Although he appeared to reject the assumption of the emperor title, according to Maech'ónyarok, it was Kojong who manipulated high-ranking officials to submit those memorials in order to demonstrate that there was a strong demand from the whole nation.

...Since the Year of Ǔlmi (1895), the [Korean] government understood Kojong's willingness to become an emperor and thus suggested the assumption of the title to the King. However, other foreign ministers, including those from Russia, France and the United States, said it should not happen and even Japanese Minister Miura Gorō advised the King to wait further for the right moment.

Afterwards, since Miura Gorō committed crimes [the assassination of Queen Min] and hence left the country, the [Korean] Government again raised an issue and started to prepare a ceremony [for the assumption of the emperor title]. However, other foreign representatives strongly opposed our plan and the Russian Minister even warned that, "Russia would terminate its diplomatic relationship if Korea announced itself to be an empire". At that time, Kojong felt threatened but also determined that he would lose face if the title assumption was disturbed at a very close stage to com-

261 May 1897, Vol.35, Kojong Silok; 9 May 1897, Vol.35, Kojong Sillok; 16 May 1897, Vol.35, Kojong Sillok; 26 May 1897, Vol.35, Kojong Sillok. 
pletion. Thus, he secretly advised some loyal officials to continuously send up memorials calling for the title assumption. In that way, he wanted it to look as if he surrendered to officials' endless demands against his will. ${ }^{27}$

The statement is consistent with what had happened since 1894, such as the change of the form of address into that of emperor. According to his argument, Kojong seemed to have been interested in becoming an emperor and stepping up to the same level as other emperors in the region. However, he was unwilling to accept it when the proposal was forcefully made by Japan and the pro-Japanese Korean ministers. Also, since Kojong witnessed that foreign representatives were very sceptical, he had to prepare a way to persuade other foreign representatives into not opposing the assumption of the emperor title. Thus, as Hwang argued in his record, Kojong's manipulation of his officials and the following rejections of the memorials intended to give an impression to foreign diplomats that it was inevitable due to popular demand.

Although those memorials to the throne were sent up at Kojong's covert requests, they are very useful to understand how Kojong and his officials justified the upgrade. The most important reason was its significance as a symbol of complete independence. Most memorials clearly mentioned the relationship between the independence of the nation and the title of emperor. For instance, I Ch'oeyŏng argued in his memorial on May 1 that;

We are currently living in the era of independence thanks to your majesty's great mercy and magnificent achievements. We thus already run an imperial system by letters and edicts, but your majesty remains at the status of king. Although King and Emperor are widely used in the same manner these days, in my humble opinion, all servants and subjects believe that there is no other

27 Hwang, Wanyǒk Maech'ǒnyarok, 409-410. 
proper title than emperor. ${ }^{28}$

On May 9, Kwŏn Talsŏp also wrote a memorial to the throne, stating the importance of the emperor title to represent the nation's independent status.

Generally, 'Cha' of 'Chaju' (self-reliance) and 'Tok' of 'Tongnip' (independence) mean that everything is entirely done by one's will without asking or relying on others. Thus, the sovereign of our independent nation must be addressed as emperor but why is your majesty not stepping up to the grand and precious status of emperor? ${ }^{29}$

On top of that, Kang Muhyŏng submitted a memorial to the king, which pointed out how different the emperor title was in Northeast Asia from that in the Western hemisphere.

Currently, Western powers use such terms as 'emperor,' 'king' or 'president'. Although it is said there is no level of difference amongst those titles, in East Asia, there has always been a hierarchy among emperors and kings. ${ }^{30}$

As mentioned, Kojong was aware that Western diplomats had been sceptical of the title assumption because they thought it would not change Korea's international status. ${ }^{31}$ Pro-Western Korean intellectuals, such as Yun Ch'iho, also shared a similar view. ${ }^{32}$ Kang's memorial clearly aimed to argue against them and justified that the acceptance of emperor title

281 May 1897, Vol. 35, Kojong Sillok.

299 May 1897, Vol. 35, Kojong Sillok.

3026 May 1897, Vol. 35, Kojong Sillok.

31 Hillier to O'Conor, 25 October 1895, Inclosure 8 in No. 128, FO 405/65.

32 Yun Chiho, Yun Chi-Ho Ilgi 4, 74. 
would be critical in the international politics of East Asia to step up to the same level as the Qing and Japanese emperors.

While openly rejecting all proposals made by high-ranking officials, Kojong started to prepare his government for his promotion to emperor. On June 14, 1897, Kojong established the 'Saryeso,' a new office dedicated to study the history of the past in order to introduce a new system suitable for an empire and appointed Chang Chiyŏn and other moderate Confucian reformers loyal to the Korean king. ${ }^{33}$ The assumption of the title of emperor was accelerated by the appointment of Sim Sunt'aek as the Prime Minister of the State Council on August 1, 1897. ${ }^{34}$ Sim was a well-known moderate Confucian reformer, who once resigned from the State Council when Japan forced Korea to reshuffle the cabinet in favor of pro-Japanese officials in 1894. He won Kojong's ultimate confidence and was praised by Kojong as 'the only person who can push ahead with the changes of the royal title and era name. ${ }^{35}$ Once Sim came into office at Kojong's request in early August 1897, he took charge of a series of events that would eventually lead to the assumption of the emperor title on October 12, 1897.

Firstly, he was ordered by Kojong to suggest a new era name after having abolished the era name 'Kŏnyang.' 36 Sim brought up two options for the new era name, 'Kwangmu' (Announcing strength) and 'Kyŏngdŏk' (Celebrating the King's virtue), and Kojong chose the former and officially announced the first year of Kwangmu on August 16, 1897. ${ }^{37}$ When the new era name 'Kwangmu' was introduced, Kojong reaffirmed that it was

3314 June 1897, Vol. 35, Kojong Sillok; 27 June 1897, Vol. 35, Kojong Sillok; 1 July 1897, Vol. 35, Kojong Sillok; Han Youngwoo, "Taehanjegugŭi Sŏngnipkwajŏnggwa Taeryeŭigwe [The Foundation of the Korean Empire and the Royal Protocol of State Ceremony]," Han'guksaron [The Study of Korean History] 45 (June 2001): 206.

341 August 1897, Vol. 35, Kojong Sillok.

35 Hwang, Wanyŏk Maech'ŏnyarok, 406.

3612 August 1897, Vol. 35, Kojong Sillok; 13 August 1897, Vol. 35, Kojong Sillok.

3715 August 1897, Vol. 35, Kojong Sillok; 16 August 1897, Vol. 35, Kojong Sillok. 
necessary to strengthen the independent status of the nation.

I will eventually restore the traditional system, uphold the ancestral law and hope to restructure them with my rule. I will establish diplomatic relations with other neighbors for friendship and co-prosperity and establish a foundation for independence. Hence, I modify the laws and regulations by taking current situations into account while referring to the existing ones. ${ }^{38}$

The introduction of the new era name encouraged discussions about the assumption of the imperial title, especially since Kojong held ritual ceremonies for the celebration of the new era name at Won'gudan on August 16,1897 . Won'gudan was a building exclusively dedicated to the rite of heaven. It could be only conducted by the 'son of heaven,' or the Chinese emperor in the Sinocentric and Confucian world. It is also worth noting that it was on July 12, 1895 that Kojong ordered the construction of Won'gudan for the first time, even though there were several records that rituals had been occasionally performed by the kings of the Chosŏn Dynasty, including King Sejo, at Won'gudan in the past. ${ }^{39}$ Moreover, in 1896, when Kojong ordered the royal household to set up new regulations and protocols for state ceremonies, he mentioned rituals at Won'gudan as well. ${ }^{40}$ These factors reveal Kojong's intentions to assume the title of emperor before the official declaration of it on October 12, 1897.

Once Kojong openly demonstrated his desire for the title by holding a ceremony at Won'gudan, high-ranking officials again submitted memorials to the throne from September 25, 1897. These memorials were continuously brought up to Kojong until October 3 when he finally approved

3816 August 1897, Vol. 36, Kojong Sillok.

3920 intercalary May 1895 (Lunar Calendar), Vol. 33, Kojong Sillok; 1 September 1457 (Lunar Calendar), Vol. 9, Sejo Sillok; Han Youngwoo, "Taehanjegugŭi Sŏngnipkwajŏnggwa Taeryeŭigwe," 209-210.

4024 July 1896, Vol. 34, Kojong Sillok. 
their proposals and announced he would become an emperor. These memorials stated various justifications about the emperor title, but they can be mainly divided into three: international law; Chosŏn's legitimacy as 'the successor of Ming China' (1368-1644) and the independence of the nation.

Firstly, it was the Minister of Agriculture, Commerce and Industry Kwŏn Chaehyŏng who argued that Kojong's upgrade to emperor would not be contradictory to the principles of international law. In his memorial, Kwon quoted 'Kongböp'oet'ong,' the Chinese translation of 'Das Moderne Völkerrecht der Civilisierten Staatenals als Rechtsuch Dagestellt' [The Modern International Law of the Civilised States] by Johann Caspar Bluntschli. He critically discussed specific chapters regarding the definition of emperor and argued why the title of emperor would be desirable for Kojong. ${ }^{41}$ He stated that a decision to change the royal title from king to emperor was entirely up to the nation. Furthermore, Kwon also pointed out that the imperial title should not necessarily require a vast territory within its boundary if Turkey or Japan, whose territories were relatively small in comparison with Britain or France, were still able to claim their imperial status to international society. ${ }^{42}$

While Kwon's arguments were based on international law, ViceMinister of Foreign Affairs Yu Kihwan emphasiszd the origin of the term 'emperor.' He argued that Kojong should become an emperor in the same manner as the sovereign of the Ming Dynasty had been addressed because 'Chosŏn's systems and civilisations were modelled upon those of Ming China. ${ }^{43} \mathrm{He}$ made an interesting comparison between the Korean and Western cases. He stated that the sovereigns of Germany and Austria be-

41 Kang Sanggyu, "Kojongŭi Taenaeoe Chŏngseinshikkwa Taehanjegung Oegyoŭi Paegyŏng [Domestic and Foreign Cognition of King Kojong and Diplomacy of Daehanjeguk]," Han'guktongyangjŏngch'isasangsayŏn'gu [The Review of Korean and Asian Political Thoughts] 4, no. 2 (September 2005): 120-122.

4225 September 1897, Vol. 36, Kojong Sillok.

4326 September 1897, Vol. 36, Kojong Sillok. 
came emperors because they claimed to have inherited the legitimacy of the Roman Empire. Thus, he concluded that the same principle should be applied to Korea because Qing China and Chosŏn had inherited the legacy of Ming China. ${ }^{44}$

The movement for Kojong to become emperor reached its peak when 716 Confucian scholars and officials, led by the highly respected Kim Chaehyŏn, memorialized Kojong on September 29, 1897. The memorial included a variety of opinions demanding Kojong's assumption of the imperial, including those based on international law and Chosŏn's alleged legitimacy. Additionally, the memorial emphasized the necessity for an imperial title to underpin the independence of Korea. It stated that various Korean states in the past such as Silla, Koguryŏ, Paekche, Kaya, Yemaek and T'amna claimed their sovereigns as kings. The memorial argued Chosŏn deserved to become an empire since all those nations had been united into one nation. ${ }^{45}$

Once Confucian scholars showed their firm support, Prime Minister Sim Sunt'aek and other ministers from September 30, 1897 officially called on Kojong to assume the title of emperor despite Kojong's continuous rejections. ${ }^{46}$ On October 2, 1897, even an ordinary subject named 'Chŏng Chaesŭng' presented a memorial to Kojong for the same purpose. Since Kojong and Sim Sunt'aek had been preparing for the king's promotion to emperor for some time, such requests made by the high-ranking officials as well as commoners aimed to demonstrate that Kojong had gained wide support from all different classes and that Kojong could not help but accept the demand. ${ }^{47}$

4426 September 1897, Vol. 36, Kojong Sillok.

4529 September 1897, Vol. 36, Kojong Sillok.

4630 September 1897, Vol. 36, Kojong Sillok; 1 October 1897, Vol. 36, Kojong Sillok; 2 October 1897, Vol. 36, Kojong Sillok.

47 The Independence Club also played a crucial role in mobilising popular support for the assumption of the emperor title. Vipan Chandra, "Sentiment and Ideology in the Nationalism of the Independence Club (1896-1898)," Korean Studies 10 (1986): 18-19. 
On October 3, 1897, when Sim had an audience with Kojong to persuade him to take on the title of emperor, Kojong finally agreed and said, "I unwillingly accept it because I cannot eventually refuse the request made by the whole nation." 48 Having once approved it, Kojong issued various orders regarding the title of emperor in a very short time. On the same day, Kojong selected October 12, 1897 for his announcement to become an emperor, which was only nine days after his approval. On October 11, 1897, Kojong announced that the country would be renamed as 'Taehan. ${ }^{49}$ On October 12, 1897, Kojong officially became emperor and changed the name of the country into the Taehan Empire. Kojong's proclamation included all the justifications of for the imperial title, which had been continuously mentioned and discussed in previous memorials by various figures. He particularly emphasised that he assumed the title of emperor only because "various officials, people, soldiers and merchants called for it in one voice." 50

Despite Kojong's careful and thorough approach, Britain was not convinced this would be the best way to secure the independence of Korea. The main principles of Britain's Korea policy, as of March 1897, could be seen in British Minister to China Claude M. MacDonald's secret audience with Kojong during his short visit to Korea. During this meeting, Kojong asked the British government to support the continued independence of Korea because Britain's "political and commercial interests in the peninsula gave her a claim to a voice in Corean affairs." 51 MacDonald answered that Britain took the "deepest interest in the maintenance of Corean independence" and advised Kojong that the best way to achieve it would be the modernization of the Korean administration to a level that other Powers would not dare to challenge its integrity. ${ }^{52}$ It indicates that

483 October 1897, Vol. 36, Kojong Sillok.

4911 October 1897, Vol. 36, Kojong Sillok.

5013 October 1897, Vol. 36, Kojong Sillok.

51 MacDonald to Salisbury, 30 March 1897, No. 74, FO 405/73.

52 MacDonald to Salisbury, 30 March 1897, No. 74, FO 405/73. 
what Britain saw as the best option for Korean independence was the reform and the improvement of the Korean government, not the redecoration of the title of the sovereign. In his conversation with the Japanese Minister, MacDonald also confirmed that the maintenance of Korean independence is one of "practically equal" interests that Britain shared with Japan. ${ }^{53}$ Considering the fact that Britain had already been aware of the Romanov-Yamagata agreement of 1896, which intended to maintain the status quo in Korea, what MacDonald meant for Britain's political interest in Korea was to prevent the country from falling into the hands of the Russian Empire.

For those reasons, the British Consulate-General in Seoul was uninterested in the debates over the imperial title until early October 1897, when Kojong finally accepted the title after rejecting a series of memorials. In his correspondence sent on October 5, 1897, British Consul-General in Seoul John Newell Jordan mentioned that the movement had been recently propelled by gaining a larger number of supports in the last few days before Kojong's approval. Jordan discussed two main points regarding the title change. Firstly, Jordan saw the question of the imperial title as a domestic issue rather than a diplomatic concern. He argued that it would not change the independent status of Korea because 'Taegunju,' the current term of address for the sovereign of Korea, was already recognized by other Powers as an equal counterpart. Jordan correctly explained that the assumption of the title of emperor would be a necessary step for Kojong's own people to "emphasize their newly acquired independence." 54 As he analyzed, the assumption of the title was welcomed by numerous Korean intellectuals. The Independent, a Korean newspaper published by the Independence Club, emphasized that the movement for the acceptance of the title had been propelled by "his multitudinous loyal subjects" and praised it as the "unanimous desire of the official class to do the honor to

53 MacDonald to Salisbury, 30 March 1897, No. 75, FO 405/73.

54 Jordan to MacDonald, 5 October 1897 Inclosure 1 in No. 142, FO 405/73. 
their Sovereign as the ruler of an independent country." 55

Secondly, he argued that Kojong's change in title to emperor would only upset Qing China, who had traditionally claimed its suzerainty over Korea. Jordan believed that the Chinese Emperor would be never willing to see their former vassal proclaim "a title which he considers so exclusively his own." In fact, since May 1897 when Korean officials started to bring up memorials calling for the imperial title, Tang Shaoyi, the Chinese Consul-General in Seoul, even reported on the movement in detail to Beijing and urged the Qing Government to take any action that could prevent foreign powers from recognizing Kojong's imperial title. ${ }^{56}$ Rather, Jordan stated that China's stubborn attitude was one of the main reasons why Korea decided to take such actions. The signing of the China-Korea Treaty of 1899, which later officially recognized the title of the Korean emperor, was also seen as the beginning of a new era, where Korea and China would equally treat each other and forge a friendly relationship between two countries. ${ }^{57}$

Considering the fact that Kojong cautiously and yet continuously took measures for the proclamation of emperor since 1894, it is noteworthy how thoroughly Kojong planned to become emperor and raise his nation's profile within international society. Not only did Kojong wait for the right timing to avoid foreign opposition, but he also carefully manipulated government officials and Confucian scholars to justify his upgrade. Continuous memorials brought up by many figures from different backgrounds, provided theoretical backgrounds for the title assumption and demonstrated the general people's support for it. Despite Kojong's elaborate efforts to legitimize the assumption of the imperial title, however, there was a

55 J. Giacinti, "His Majesty, the King, is Now Emperor of Korea", 5 Oct 1897, The Independent.

56 Lee Kooyong, “Taehanjegugŭi Sŏngnipkwa Yŏlgangŭi Panŭng - Ch'ingjegŏnwŏn Nonŭirŭl Chungshimŭro [The Great Powers' Attitude with reference to the Founding of Taehan Empire]," Kangweong Sahak, 1 (December 1985): 75-97. (88-90)

57 Cho, Hwangje Chungshimŭi Kŭndae Kukkach'eje Hyŏngsŏng: Kojonggwa Taehanjeguk, 74-75. 
fundamental difference between Britain and Korea in maintaining the integrity of Korea. Britain clearly wanted the maintenance of Korean independence, which would eventually counterbalance Russian influence in the country. Britain firmly believed that the modernization and the strengthening of the Korean administration would be the most appropriate and plausible way to achieve it, while they understood that Kojong's assumption of the imperial title would only have marginal impact upon domestic politics of Korea.

\section{British Recognition of Kojong's Proclamation of Becoming Emperor}

Therefore, as discussed above, Britain was convinced that the impact of the recognition of Kojong as emperor would be very limited. The importance of the imperial title did not significantly increase since 1895 when Britain joined other foreign representatives and opposed the proclamation of the title. However, since the imperial title was accepted by Kojong, the British Government clarified that they would not prevent Jordan from acknowledging Kojong as emperor if other foreign representatives in Seoul did the same. ${ }^{58}$ On November 10, 1897, nearly a month after Kojong's assumption of the title of emperor, the Japanese government officially proclaimed that they would use the term 'emperor,' regardless of other foreign powers. ${ }^{59}$ Afterwards, on December 18, 1897, the Russian Czar sent a congratulatory telegram to Kojong for his assumption of the title of emperor. ${ }^{60}$ Russian recognition was later officially published in the official Gazette and taken as a "special token of friendly feeling on the part of Russia." ${ }^{1}$ France also recognized Kojong as emperor on the grounds that Kojong could decide the titles of the sover-

58 Foreign Office to Jordan, 30 December 1897, FO 405/73.

59 CIK, Nish to Katō, 10 November 1897, No. 57, Vol. 12.

60 Jordan to MacDonald, 26 December 1897, Inclosure in No.10, FO 405/80.

61 Jordan to MacDonald, 4 January 1898, Inclosure in No. 47, FO 405/80. 
eign and the state because he was an independent sovereign. Furthermore, since other countries did not oppose Kojong's imperial title, France made clear that they would recognize Kojong as emperor without any objection. ${ }^{62}$

Following Japan, Russia, and France, the United States also recognized the imperial title by using the term in correspondences between Kojong and the President of the United States. Therefore, Jordan respected the instructions given by the British Foreign Office to follow the action taken by the majority of foreign representatives in Seoul and told the Korean Minister of Foreign Affairs Cho Pyŏngsik that he would use the new title in his future correspondences with the Korean government. Although he followed London's instruction and recognized Kojong's new title as emperor, Jordan was reluctant to attach any special significance to it. Therefore, Jordan only informed Cho verbally without any manuscript that would be used by the Korean government as formal proof of British recognition of the Korean emperor. ${ }^{63}$ Britain's passive stance obviously reveals the fundamental principle of Britain's Korea policy, where Britain maintained its non-interference policy when an external threat from a hostile power was non-existent and actively intervened only when British presence in the country was challenged. ${ }^{64}$ Despite the marginal and verbal recognition, Kojong expressed his gratitude to Jordan for British recognition and interpreted it as "the interest which Her Majesty's government took in Korea" and "a token of their goodwill towards himself personally." 65

62 Cho, Hwangje Chungshimŭi Kŭndae Kukkach'eje Hyŏngsŏng: Kojonggwa Taehanjeguk, 72-73.

63 Jordan to Foreign Office, 25 February 1898, No. 79, FO 405/80.

64 For the origin of Britain's non-interference policy in Korea, see Han Seunghoon, "Koripchŏngch'aekkwa Kansŏpchŏngch'aegŭi Ijungju: Choilsuhojogyue Taehan Yŏnggugŭi Inshikkwa Taeŭng [Isolation and Intervention: the British Governments Appreciation and Response to the Kanghwa Treaty (1876)], 'Yŏksabip'yŏng [Critical Review of History] 114 (February 2016): 57-81.

65 Jordan to Salisbury, 9 March 1898, No. 83, FO 405/80. 
Coincidentally, after Britain had recognized Kojong's assumption of the title of emperor, the rank of the British representative in Seoul was promoted from consul-general to chargé d'affaires. On March 8, 1898, John Newell Jordan was officially appointed the British Chargé d'affaires in Korea and he notified the Korean government on the following day. ${ }^{66}$ Due to the timing, the promotion of the rank of the British representative in Korea is sometimes interpreted as one of the measures taken by Britain to acknowledge Kojong's new imperial title. However, the change of rank was originally considered for a practical reason.

The question of Jordan's diplomatic rank was raised when he found it very difficult to have an audience with Kojong in October 1897. On October 6, 1897, Jordan requested a royal audience to the Minister of Foreign Affairs Min Chongmuk to discuss the proposed replacement of John McLeavy Brown with a Russian advisor. ${ }^{67}$ Brown was a British national who served as the Chief of the Korean Customs since 1893 and as the financial adviser since 1894. As a high-ranking official in the Korean government, Brown held a crucial position and not only controlled the budget of the Korean government and the tariff revenues of the Korean Customs, but also, he took advantage of his position and attempted to maximize British interests within the country. ${ }^{68}$ However, his position

66 Jordan to Salisbury, 10 March 1898, No. 85, FO 405/80.

67 Asiatic Research Institute, Kuhan'gugoegyomunsŏ [The Diplomatic Documents of the Late Chosŏn] (Seoul: Korea University, 1965-1973), Jordan to Min Chongmuk, 6 October 1897, Yŏng'an [UK Collection] vol. 1. For more information on the Anglo-Russian confrontation regarding the position of John McLeavy Brown, see Kim Hyunsook, "Taehanjegukki t'akchibugomun allekseyep'ǔŭi chaejŏngjŏng ch'aekkwa ch'illŏhwaltong [The Financial and Pro-Russian Policy by K. Alexeiev during the Han Empire Period]," Han'gukkŭnhyŏndaesayŏn'gu [Journal of Korean Modern and Contemporary History] 47 (December 2008): 92-101.

68 Kim Hyunsook, "Hanmal Komun'gwan J. McLeavy Browne Taehan Yŏn'gu[The Politics of Foreign Advisers in Korea with Special Reference to J. McLeavy Brown]," Han'guksayŏn'gu[The Journal of Korean History] 66 (September 1989): 107. 
was threatened by the proposed appointment of a Russian advisor, Karl Alexeiev. The appointment of Alexeiev was based on a secret agreement signed by the Russian Finance Minister Sergei Iulievich Witte and Korean Special Envoy Min Yŏnghwan in April 1896, which stipulated that Russia would provide various advisors and loans to the Korean government. ${ }^{69}$ Despite his high hopes, Kojong was soon disappointed when he found that Russia had already signed an agreement with Japan regarding the maintenance of the status quo in Korea, which was one of the reasons why he left the Russian legation and returned to the royal palace. However, Russia still took advantage of the existing agreement between Korea and Russia. They attempted to strengthen its influence and to undermine British presence in the country by replacing Brown with Alexeiev. Britain saw it as a serious challenge to their interests and was determined to respond by all means available.

Regarding this question, British Minister in Qing China Claude M. MacDonald was authorized by the Foreign Office to instruct Jordan to warn Kojong that the British government would be furious if Brown, the chief of the Korean Customs and the financial advisor, were to be sacked. ${ }^{70}$ Hence, Jordan attempted to deliver Britain's official objection to the appointment of a Russian advisor during his audience with Kojong. However, Minister Min declined Jordan's requests of an audience with Kojong for several reasons, such as unexpectedly prolonged audiences or Kojong's ill-health. ${ }^{71}$ Despite all the excuses given by Min Chongmuk,

69 Kim Hyunsook, “Taehanjegukki t'akchibugomun allekseyep'ǔŭi chaejŏngjŏngch'aekkwa ch'illŏhwaltong."

70 MacDonald to Salisbury, 5 October 1897, No. 111, FO 405/73; Salisbury to MacDonald, 6 October 1897, No. 112, FO 405/73.

71 Min Chongmuk to Jordan, 6 October 1897, Yŏng'an vol. 1; Min Chongmuk to Jordan, 7 October 1897, Yŏng'an vol. 1; Jordan to Min Chongmuk, 8 October 1897, Yŏng 'an vol. 1; Min Chongmuk to Jordan, 9 October 1897, Yŏng 'an vol. 1; Jordan to Min Chongmuk, 12 October 1897, Yǒng'an vol. 1; Jordan to Min Chongmuk, 13 October 1897, Yŏng'an vol. 1; Min Chongmuk to Jordan, 13 October 1897, Yŏng'an vol. 1. 
Jordan was already aware that Kojong was perfectly healthy to meet other cabinet and foreign ministers.

On October 7, 1897, after rejecting Jordan's request, Min reminded Jordan that he could only claim an audience with Kojong as a favor due to his rank as consul general. ${ }^{72}$ After his attempts to transmit his messages via interpreters also failed due to Russian interference, he realized that as a consul general it would be impossible to deliver Britain's opposition to the replacement of Brown. Although he appealed to Min that his activities as the British representative in Korea had never been disturbed, London confirmed that audience with the sovereign could not be claimed by a British consul-general in accordance with international protocols unless other foreign consuls were given the same privilege. ${ }^{73}$

It was this moment Britain realized that a consul-general would be unable to properly defend British interests in Korea, and at a time when Russian penetration into the country was imminent. Previously, the British consul-general in Seoul was generally treated by Kojong as equal to other foreign representatives whose diplomatic ranks were either Chargé d'affaires or Minister. Kojong usually had audiences at the requests of the British Consul-General and even consulted urgent and important issues with them on several occasions, including the Japanese murder of Queen Min or Kojong's asylum to the Russian legation. Their initial decisions regarding British interests in Korea were also respected by the British Minister to Beijing and the Foreign Office in London, even though they required the former's approval due to diplomatic formality. However, when the Korean government notified that Brown would be removed from his current position as the financial advisor, Anglo-Russian rivalry became fierce in early October 1897. Kojong took advantage of the low rank of the British representative to Korea and used it to avoid a direct confrontation with Britain.

Hence, the British Minister in China MacDonald strongly argued that

72 Jordan to MacDonald, 8 October 1897, Inclosure in No. 83, FO 405/73.

73 Salisbury to MacDonald, 22 December 1897, No. 170, FO 405/73. 
the British representative in Seoul should have the right to request an audience with Kojong especially in order to solve the question of the position of Brown. ${ }^{74}$ Salisbury and MacDonald discussed what diplomatic rank should be given to Jordan. Salisbury suggested the rank of minister resident, the same rank as other foreign representatives in Korea, should be given to Jordan. ${ }^{75}$ MacDonald replied that chargé d'affaires, a lower rank than minister-resident, would be reasonable for the British representative in Korea. ${ }^{76}$ Considering Britain carefully designed their diplomatic network in Northeast Asia, it reflects Britain's cautious and yet practical policy towards Korea because a chargé d'affaires could request an audience with the sovereign and yet it left space for further development, depending on the future of Anglo-Korean relations. On March 9, 1898, Jordan duly notified the Korean Minister of Foreign Affairs that he had been appointed as Chargé d'affaires in Korea. In response, Minister Min and Kojong expressed their pleasure and satisfaction to him on the same day. ${ }^{77}$

Because of the coincidental timing, it is sometimes argued that the promotion of the British representative to chargé d'affaires was related to Britain's recognition of the official assumption of Kojong's new title as emperor. ${ }^{78}$ It is true that the Korean government raised the question of the rank of the British representative in October 1897 amid the assump-

74 MacDonald to Salisbury, 15 February 1898, No. 32, FO 405/80.

75 Salisbury to MacDonald, 18 February 1898, No. 33, FO 405/80.

76 MacDonald to Salisbury, 19 February 1898, No. 34, FO 405/80; MacDonald to Salisbury, 21 February 1898, No. 36, FO 405/80.

77 Jordan to Salisbury, 10 March 1898, No. 85, FO 405/80. Japan also advised Britain to promote the diplomatic rank of the British representative in Seoul in order to enhance bilateral cooperation in Korea. Hyun Kwangho, "Taehanjegukki Kojongŭi Taeyŏng Chŏngch'aek [A policy toward Great Britain of King Kojong in the Great Han Empire]," Han'guksayŏn'gu [The Journal of Korean History] 140 (March 2008): 228.

78 Lee Minwon, “Taehanjegugŭi Sŏngnipkwajŏnggwa Yŏlganggwaŭi Kwan'gye,” 142. 
tion of Kojong's new imperial title. If Kojong believed it was essential to have a British chargé d'affaires or a minister-resident as a sign of international recognition of the complete independence of Korea, then he seems to have successfully taken it as an opportunity to press Britain. Furthermore, since Kojong revealed his "satisfaction" when Jordan informed him of his appointment as chargé d'affaires, it is possible that to some extent Kojong saw it as a significant step for Britain to acknowledge the independence of Korea.

However, at the same time, the main reason why London decided to change the rank of the British representative in Korea was very practical. Britain did not change an affiliation between the British legation in China and the British Consulate-General in Korea when the First Sino-Japanese War ended with China's recognition of Korean independence. When the Korean government under Japanese influence discussed the assumption of Kojong's new title as emperor immediately after the murder of Queen Min in 1895, Britain was very cautious of the proposed new title because, besides the fact that Kojong's current title as 'king' would be sufficient to be recognized by other countries as an equal sovereign, the proposal was obviously made by Japan and it would eventually damage the integrity of Korea if such a measure would be taken against Kojong's will. Britain did not appoint a chargé d'affaires until the British presence in Korea was seriously challenged by a hostile power and the rank of consul-general was incapable of defending those interests. This gap between Korea and Britain over the questions of the new imperial title and the rank of the British representative shows how much their expectations differed from each other.

\section{Conclusion}

Kojong's assumption of the new title aimed to redefine Korea's centuries-long tributary relationship with China and to reclaim its position as an independent country, especially when the regional order was chal- 
lenged by the rise of Japan. To avoid any objection from foreign representatives, which he had already faced in 1895 , Kojong took a very cautious and patient approach for months by building up justifications on why Kojong should assume a new imperial title. Kojong and his officials argued that the title of emperor would represent the complete independence of Korea and raise Korea's status to the same level as China and Japan. Additionally, Kojong and Korean officials developed counterarguments against possible foreign opposition by critically examining international law.

Despite Kojong's cautious approach, foreign powers, especially Britain, were indifferent to the question. Due to the coincidence of Kojong's title assumption and Britain's appointment of a chargé d'affaires, the latter was seen as British recognition of the Korean imperial title and the independence of Korea. This may be true to some extent, particularly because Kojong vigorously attempted to achieve Korean independence by diplomacy. However, from the British perspective, Britain promoted the rank of the highest British representative in Korea only when British interests in the country were seriously challenged and the British consul-general could not efficiently defend them due to the low diplomatic rank.

Korea's preoccupation with the proclamation of the title of emperor and Britain's practical approach towards the question of the imperial title clearly reveal their different postures towards the question of Korean independence. Kojong attempted to redefine the independence of Korea by declaring himself emperor and consequently improving Korea's position in East Asia, whereas Britain believed that it was a waste of political capital and material resources for the sake of highlighting Korean independence, which had already been affirmed by existing treaties. This case is a typical example to show the differences between Korea and Britain in their policies towards Korean questions. While Korea relied upon diplomacy due to its relative weakness in comparison with neighboring countries, Britain preferred practical approaches to deal with Korea's immediate problems, such as inefficient governance and widespread corruption. This gap between the two countries would eventually contribute to the 
deterioration of Anglo-Korean relations when Japan emerged as a strategic partner of Britain and Britain recognized Japan's special interest in Korea in the Anglo-Japanese Alliance of 1902.

\section{Bibliography}

1. Asiatic Research Institute. Kuhan'gugoegyomunsŏ [The Diplomatic Documents of the Late Chosŏn] Seoul: Korea University, 1965-1973.

2. Giacinti, J. "His Majesty, the King, is Now Emperor of Korea", 5 Oct 1897, The Independent.

3. Hwang, Hyun. Wanyŏk Maech'ǒn yarok Seoul: 1994.

4. Kyujanggak Seoul. Kojong Sillok [Annuals of Kojong Era], Vols. 3346.

5. National Institute of Korean History. Chuhan Ilbon'gongsagwan Kirok [he Records of the Japanese Legation Korea] Kwach'ŏn: National Institute of Korean History, 1988-1994.

6. The National Archives, Kew, United Kingdom. Foreign Office (FO) 405: China and Taiwan Confidential Print.

7. Yun, ChiHo. Yun Chi-Ho Ilgi, 6 vols. Seoul: National History Compilation Committee, 1975.

8. Chandra, Vipan. "Sentiment and Ideology in the Nationalism of the Independence Club (1896-1898)." Korean Studies 10 (1986): 13-34.

9. Cho, Jaegon. Hwangje Chungshimŭi Kündae Kukkach'eje Hyŏngsŏng : Kojonggwa Taehanjeguk/The Emperor-Centred Formation of a Modern State System] Seoul: Yŏksagonggan, 2020.

10. Cook, Harold F. Korea's 1884 Incident: Its Background and Kim OkKyun's Elusive Dream Seoul: Royal Asiatic Society Korea Branch, 1972.

11. Han, Seunghoon. "19segi Huban Chosŏnŭi Taeoejŏngch'aek Kijowa Kŭ Shirhyŏn: Kyunsejŏngch'aekkwa Kŏjungjojŏngŭi Ch'ujin [Establishment and Enforcement of Foreign Policy in the Late 19th Century of Chosŏn with Regard to Balance of Power and Good Offices].” 
Han'gukkŭnhyŏndaesayŏn'gu [Journal of Korean Modern and Contemporary History] 83 (December 2017): 7-38.

12. Han, Seunghoon. "Ch'ŏngilchŏnjaeng Chikchŏn Yŏnggugŭi oegyojŏk Kansŏp Shilp'aewa P'aegwŏnjŏk Chiwi Kyunyŏl: Yŏnggugŭi Taejosŏnjŏngch'aekkwa Kwallyŏnhaesŏ[Britain's failure to intervene in diplomacy before the first Sino-Japanese War and the Cracking of its Hegemony: with Regard to British Policy toward Korea].” Han'guktongyangjöngch'isasangsayŏn'gu [The Review of Korean and Asian Political Thoughts] 19, no.2, (September 2020): 63-97.

13. Han, Seunghoon. "Choyŏngjoyak(1883. 11)kwa Pulp'yŏngdŭngjoyakch'ejeŭi Chaejŏngnip [The Treaty Concluded between Korea and Britain in 1883 and the Reconstruction of the Unequal Treaty System]." Han'guksayŏn'gu [Journal of Korean History] 135 (December 2006): 215-250

14. Han, Seunghoon. "Koripchŏngch'aekkwa Kansŏpchŏngch'aegŭi Ijungju: Choilsuhojogyue Taehan Yŏnggugŭi Inshikkwa Taeŭng[Isolation and Intervention: the British Governments Appreciation and Response to the Kanghwa Treaty (1876)]." Yǒksabip'yŏng [Critical Review of History] 114 (February 2016): 57-81.

15. Han, Youngwoo. "Taehanjegugŭi Sŏngnipkwajŏnggwa Taeryeŭigwe [The Foundation of the Korean Empire and the Royal Protocol of State Ceremony]." Han'guksaron [The Study of Korean History], 45 (June 2001), 193-277

16. Hyun, Kwangho. “Taehanjegukki Kojongŭi Taeyŏng Chŏngch'aek [A Policy toward Great Britain of King Kojong in the Great Han Empire]." Han'guksayŏn'gu [The Journal of Korean History] 140 (March 2008), 221-248

17. Kang, Sanggyu. "Kojongŭi Taenaeoe Chŏngseinshikkwa Taehanjegung Oegyoŭi Paegyŏng [Domestic and Foreign Cognition of King Kojong and Diplomacy of Daehanjeguk]." Han'guktongyangjŏngch'isasangsayŏn'gu [The Review of Korean and Asian Political Thoughts] 4, no. 2 (September 2005), 105-129

18. Kim, Hyunsook. "Hanmal Komun'gwan J. McLeavy Browne Taehan 
Yŏn'gu[The Politics of Foreign Advisers in Korea with Special Reference to J. McLeavy Brown]." Han'guksayŏn'gu[The Journal of Korean History] 66 (September 1989): 103-156.

19. Kim, Hyunsook. "Taehanjegukki t'akchibugomun allekseyep'ǔŭi chaejŏngjŏngch'aekkwa ch'illŏhwaltong [The Financial and ProRussian Policy by K. Alexeiev during the Han Empire Period]." Han'gukkŭnhyŏndaesayŏn'gu [Journal of Korean Modern and Contemporary History] 47 (December 2008): 80-113.

20. Kim, Hyunsoo. "Yŏngguk Oegyojŏngch'aegŭi Pyŏnhwach'ui, 1860 1914: Taejungguk Oegyojŏngch'aek Chungshimŭro[Trend of the British Foreign Policy to China, 1860 1914]." Tongyanghak[The Oriental Studies] 67 (2017): 91-108

21. Kim, Jong-Heon, "Ch'ŏngil Chŏnjaeng Ihu Chaehan Rŏshia Oegyogwanŭi Hwaltonge Kwanhan Koch'al, 1894-1895[A Study on Activities by Russian Diplomats after the Sino-Japanese War, 18941895]," Süllabŭhakpo[Slave Newpaper] 24, no.2 (Jun 2009): 273-298.

22. Kim, Keyhiuk. The Last Phase of the East Asian World Order: Korea, Japan and the Chinese Empire, 1860-1882. Berkeley, California: University of California Press, 1980.

23. Kim, Wonsoo. “4kuk'yŏpchoch'ejewa Hanilbyŏnghabŭi Kukchegwan'gye, 1907 1912: Yŏnggugŭi Tongmaenghyŏpsangoegyowa Yŏn'gyehayŏ[International Relations of the Quadruple Entente System and the Japanese Seizure of Korea, 1907 1912 : Related to the British Entente Policy].” Dongbuga Yeoksa Nonchong 29 (September 2010): 55-96

24. Kim, Wonsoo. "Ilbonŭi Taehanjeguk Pohoguk'wawa Yŏnggugŭi Taehanjŏngch'aek: Yŏngiltongmaenggwa Rŏilchŏnjaengŭl Chungshimŭro[British Policy toward Korea before and after Japan`s Protectoration of Korea: Focused on the Anglo-Japanese Alliance and the Russo-Japanese War]." Han'guktongnibundongsayŏn'gu[Journal of Korean Independence Movement Studies] 51 (August 2015): 187-215.

25. Ku, Taeyul. "Chayujuŭi yŏlgangŭi Hanbando Chinch'ulgwa Kŭ Sŏnggyŏk, 1870-1910[The Nature of Liberal Powers' Advance to- 
wards the Korean Peninsula]." Han'guksasanggwa Munhwa[Korean Ideology and Culture] 21 (September 2003): 7-54

26. Lee, Eunja. "Hanjung Kŭndae Oegyoŭi Shirhŏm, 1895-1905Nyŏn [The Challenges to the Modern Diplomacy Between Korea and China, 1895-1905]." Chunggukkŭnhyŏndaesayŏn'gu [Korean Studies of Modern Chinese History] 58 (June 2013): 1-25

27. Lee, Kooyong. "Taehanjegugŭi Sŏngnipkwa Yŏlgangŭi Panŭng Ch'ingjegŏnwŏn Nonŭirŭl Chungshimŭro [The Great Powers' Attitude with reference to the Founding of Taehan Empire]." Kangweong Sahak 1 (December 1985): 75-97

28. Lee, Minwon. “Taehanjegugŭi Sŏngnipkwajŏnggwa Yŏlganggwaŭi Kwan'gye [On the Response of the Foreign Powers to the Establishment of the Taehan Empire]." Han'guksa Yŏn'gu [The Journal of Korean History] 64 (March 1989), 117-145

29. Min, Hoisoo. "Kabogaehyŏng ijŏn chosŏnŭi hwangjegung yongŏ sayong [The Use of the Terms for the Empire in Korea before 1894]." Kyujanggak 55 (December 2019), 123-150

30. Park, Eunsook. Kapsin chŏngbyŏn Yŏn'gu [A Study of Kapsin Coup]. Seoul: Yŏksabip'yŏngsa, 2005.

31. Seo, Younghee. Taehanjeguk chŏngch'isa yŏn'gu[The Study of the Political History of the Great Han Empire]. Seoul: Seoul National University Press, 2003.

32. Song, Kuejin. Transformation of the Dualistic International Order into the Modern Treaty System in the Sino-Korean Relationship." International Journal of Korean History 15, no.2. (August 2010): $97-$ 126

33. Tsukiashi, Tatsuhiko. Chosŏnŭi Kaehwasasanggwa Naesyŏnŏllijŭm[The Enlightenment Ideas and Nationalism of Chosŏn], trans. Duk-Soo Choi. Paju: Yŏllinch'aektŭl, 2014. 
$<$ Abstract $>$

\section{Ascending to the Imperial Throne: Kojong's Assumption of Emperor Title and British Response to the Question, 1895-1898}

This article aims to examine the objective and the background of Kojong's assumption of the title of emperor in 1897 and the British response. Kojong's assumption of the new imperial title mainly aimed to end Korea's centuries-long tributary relationship with China and to reclaim its position as an independent country, which had been damaged by severe political events, such as the Japanese murder of Queen Min and Kojong's asylum at the Russian Legation. To avoid any objection from foreign representatives, which he had already faced in 1895 , Kojong took a very cautious and patient approach for months by building up justifications on why Kojong should assume a new imperial title. Kojong and his loyal officials mainly argued that the title would represent the complete independence of Korea and raise Korea's status to the same level as China and Japan. However, foreign powers, especially Britain, were indifferent to the question of the assumption of the imperial title because their primary interest in the country, which was to balance Russia's advance towards Korea, could not be achieved by a change in title. This show differences between Korea and Britain in their policies towards Korean questions.

Keywords: Anglo-Korean Relations, Emperor Kojong, Diplomatic History, Taehan Empire, Korean History, 


\section{〈국문초록〉}

\section{황제로의 즉위: 고종의 칭제와 영국의 반응, 1895-1898}

권의석 (원광대학교 $\mathrm{HK}+$ 연구교수)

본 논문은 고종의 1897 년 칭제 및 대한제국 선포의 배경 및 과정과 이에 대한 영국

의 반응을 살펴본다. 고종이 1897년에 칭제를 하게 된 데에는 수 세기 동안 이어져온 청과의 조공-책봉 관계를 청산하고자 하는 목적과 함께, 1895년 을미사변, 1896년 아관 파천 등으로 훼손된 국격을 재고하여 독립국으로서의 국제적 지위를 향상시키고자 하 는 데 목적이 있었다. 1895 년 일본의 영향 하에서 칭제가 강제로 추진되었다가 각국 외교관들의 반대에 부딪힌 경험을 반면교사로 삼아, 고종은 매우 조심스럽고 인내심있 는 접근을 통해 왜 황제에 즉위해야 하는지에 대한 명분을 꾸준히 쌓았다. 고종과 그 의 신하들은 황제 즉위가 한국의 완전한 독립을 강조하고 한국의 국제적 지위를 중국 과 일본의 그것으로 올릴 수 있다고 주장하였다. 하지만 해외 열강, 특히 영국은 이 문 제에 대해 심드렁한 태도를 취하였는데, 이는 영국의 한국정책 목적이었던 러시아의 한국 진출 저지를 고종의 황제 즉위로 이룰 수 있는 게 아니었기 때문이다. 이 문제에 대한 한영 간의 태도 차이는 한국 문제를 바라보는 양국 정부의 근본적으로 다른 시각 을 반영한다.

주제어: 한영관계, 고종 칭제, 외교사, 대한제국, 한국근대사 
